\title{
Brexit and Corporate Citizenship
}

\author{
John Armour ${ }^{1,2}$ - Holger Fleischer ${ }^{3,4}$ - Vanessa Knapp ${ }^{5}$. \\ Martin Winner 6,7
}

(C) The Author(s) 2017. This article is an open access publication

\begin{abstract}
The UK's recent vote for Brexit has sparked a fierce debate over the implications for the rights of EU citizens living in the UK and UK citizens living in the rest of the EU. So far, however, there has been relatively little discussion of the implications of Brexit for legal persons - that is, corporate citizens of the EU, which may also be profoundly affected by consequent changes. The ECJ's 1999 decision in Centros made clear that the freedom of establishment protects the entitlement of corporate persons formed in one EU Member State to carry on their business in another Member State. Since then, many entrepreneurs in continental European countries have chosen to form companies in the UK, while still carrying on their business in their home country. What will the consequences of Brexit be for such companies?
\end{abstract}

While the authors are members of the European Commission's Informal Company Law Expert Group (ICLEG), this paper does not form part of the work of ICLEG, nor do the views expressed in it reflect the position of the European Commission. We thank Luca Enriques, Harm-Jan de Kluiver, Bartek Kurcz and Wolf-Georg Ringe for helpful comments on earlier drafts.

$\triangle$ John Armour

john.armour@law.ox.ac.uk

1 Hogan Lovells Professor of Law and Finance, University of Oxford, Oxford, UK

2 Research Fellow, European Corporate Governance Institute, Brussels, Belgium

3 Director of the Max Planck Institute for Comparative and International Private Law, Hamburg, Germany

4 Research Associate, European Corporate Governance Institute, Brussels, Belgium

5 Visiting Professor, Queen Mary University of London, London, UK

6 Professor of Business Law and Director of the Department of Information and Intellectual Property Law, Vienna University of Economics and Business, Vienna, Austria

7 Chairman of the Austrian Takeover Commission, Vienna, Austria 
Keywords Brexit - Centros · Company law · Conflict of laws · Cross-border mergers · Freedom of establishment - Societas Europaea $\cdot$ Real seat theory

\section{Introduction}

The UK's recent vote for Brexit has sparked a fierce debate over the implications for the rights of EU citizens living in the UK and of UK citizens living in the rest of the EU. So far, however, there has been relatively little discussion of the implications of Brexit for legal persons - that is, corporate citizens of the EU, which may also be profoundly affected by consequent changes. The ECJ's 1999 decision in Centros made clear that the Treaty freedom of establishment protects the entitlement of corporate persons formed in one Member State to carry on their business in another Member State. Since then, many entrepreneurs in continental European countries have chosen to form companies in the UK, carrying on their business wholly or entirely in the jurisdiction of the founder. In addition, companies established in one Member State have been able to merge with one or more companies from one or more other Member States, with the result that they can move to another Member State. Companies can be formed or convert to as Societas Europaea (SEs), which can also move their registered office from one Member State to another. In this article, we consider the likely consequences of Brexit for such corporate citizens.

We begin in Sect. 2 with a brief review of the principles of freedom of establishment applicable to EU corporate entities, and then present empirical evidence regarding the extent to which this has been relied upon by companies formed in the UK to do business elsewhere in the EU. This gives a sense of the size of the potential problem. While the rate of such inward incorporation in the UK has declined markedly since the late 2000 s, there remain possibly as many as 330,000 such companies registered in the UK but having their business activity wholly or mainly in another EU Member State. Amongst the EU27, it appears that Germany has the largest single population of such UK-incorporated companies.

In Sect. 3, we consider what Brexit will mean for these companies' ability to rely on the freedom of establishment. In the case of a 'hard' Brexit, where the UK leaves the EU without remaining in the single market, freedom of establishment would clearly cease to apply. Even in the case of a 'soft' Brexit, where the UK remains within the single market, while UK companies would still be able to rely on freedom of establishment in relation to company law, they would encounter considerable difficulties, as they would no longer be able to make use of the European Insolvency Regulation to govern their insolvency.

We then consider, in Sect. 4, the consequences for UK companies of no longer being able to rely on freedom of establishment. We focus here on the cases of Austria and Germany, because they have high populations of UK companies and traditionally have vigorously employed the real seat theory as the connecting factor for the private international law of companies. Although a number of possibilities for damage limitation are actively debated, the mechanical application of the real seat theory could trigger the cessation of limited liability for owners of such companies. 
Having discussed issues pertaining to companies exercising freedom of establishment from their moment of formation, we then, in Sect. 5, turn to the effect of Brexit on companies making use of EU law to effect a transformation either a cross-border merger or the creation of a European Public Company (SE). There are real risks for companies undertaking such transactions, if they do not secure the necessary formalities for completion prior to cessation of the UK's membership, of getting stuck in a legal limbo where the necessary EU law framework to secure completion is no longer applicable.

Section 6 concludes with a discussion of the implications, not only for potentially affected corporate citizens, but also for UK and EU negotiators and legislators.

\section{Freedom of Establishment for Corporate Citizens Within the EU}

\subsection{Legal Framework}

Article 49 of the Treaty on the Functioning of the European Union (TFEU) provides that, "restrictions on the freedom of establishment of nationals of a Member State in the territory of another Member State shall be prohibited'. Article 54 TFEU makes clear that freedom of establishment may be relied upon by corporate as well as natural persons. Consequently, any company validly formed under the laws of a Member State is to be treated the same way as a natural person for the purpose of exercising freedom of establishment. ${ }^{1}$

The full extent to which companies are free to exercise freedom of establishment was made clear by the ECJ's decision in Centros. ${ }^{2}$ In that case, two Danish entrepreneurs formed a company (Centros Ltd) in the UK to avoid having to comply with Danish minimum capitalisation requirements. However, the Danish authorities refused to permit Centros Ltd to register a branch in Denmark, taking the view that the company carried on no business in the UK and consequently was seeking to establish not a 'branch' but its primary establishment in Denmark. The ECJ disagreed, holding that the status of a 'company', for the purpose of determining whether Article 54 meant it could enjoy the Treaty freedom of establishment, was to be decided according to the law of the Member State in which it had putatively been formed. ${ }^{3}$ All the necessary formalities for corporate formation under English law had been complied with. Consequently, Centros Ltd was capable of invoking freedom of establishment, and the refusal to register its branch in Denmark was a clear interference with this freedom.

The significance of Centros for the real seat theory was subsequently made clear in $\ddot{\text { Uberseering. }}{ }^{4}$ Überseering BV was a company validly formed in the Netherlands,

\footnotetext{
1 Case C-182/83 Robert Fearon \& Co Ltd v Irish Land Commission [1984] ECR 3677, at [8].

2 Case C-212/97 Centros Ltd v Erhvervs-og Selskabsstyrelsen [1999] ECR I-1459. For discussion, see Armour and Ringe (2011), at pp 131-143, and sources cited therein.

3 Ibid., at [17].

4 Case C-208/00 Überseering BV v Nordic Construction Company Baumanagement GmbH (NCC) [2002] ECR I-9919.
} 
where the incorporation theory was applied. The company subsequently moved its head office to Germany. The German courts, applying the real seat theory, refused to recognise Überseering BV's existence: the connecting factor directed them to German law, under which no company had validly been formed. The logic of Centros, however, dictated that the company's status as such had been established by Dutch law, and consequently the company was entitled to rely, via Article 54, on the Treaty freedom of establishment. Denial of its existence by the German court clearly restricted the exercise of the company's freedom.

Since Centros and Überseering, European entrepreneurs have, in theory, been free to select amongst EU Member States for the governing law of newly incorporated companies. ${ }^{5}$ This raises the question of how to restrict strategic selection of company laws in a way that benefits the entrepreneur at the expense of creditors or others. In principle, this should not be a matter of great concern at the point of formation, because parties who will deal with the company - outside investors, creditors and employees - are all going to enter into new contracts with it, and so will be able to price in any associated costs. The only potentially affected parties may be groups who are unable to bargain over their claims, for example, tort victims or the tax authorities. ${ }^{6}$

There are at least two routes by which Member States may be able to justify national law rules seeking to protect such constituencies. First, national law measures having an effect that is only 'indirect and uncertain' at the point of establishment will not constitute restrictions on freedom of establishment. ${ }^{7}$ It follows that whether a national law measure constitutes a restriction on the exercise of corporate freedom of establishment, at least for companies that establish themselves in a Member State at the point of formation, depends on the extent to which it would be likely to encroach on the decision-making of shareholders and directors of companies at the point such establishment takes place. ${ }^{8}$ In its recent Kornhaas decision, ${ }^{9}$ the ECJ held that national provisions of insolvency law imposing obligations on financially distressed companies and their directors for the benefit of the creditors as a whole did not affect the exercise of freedom of establishment by newly formed companies. The Court considered that insolvency was such an uncertain event at the time of formation that concerns about potential liabilities, should insolvency supervene, would be matters that would not impinge on shareholders' and directors' decision-making about corporate establishment in the host Member State at the time of formation. ${ }^{10}$

\footnotetext{
5 As a practical matter, this selection is only feasible amongst Member States that apply the incorporation theory and the Member State in which the business' seat is physically located.

6 See generally, Kraakman et al. (2017), at pp 115-116.

7 See, e.g., Case C-19/92 Kraus v Land Baden-Württemberg [1993] ECR I-1663; Case C-190/98 Graf v Filzmoser Maschinenbau GmbH [2000] ECR I-493; Joined Cases C-51/96 and C-191/97 Deliège v Ligue Francophone de Judo et Disciplines Associées ASBL [2000] ECR I-2549.

8 Armour (2005), at pp 405-406.

9 Case C-594/14 Kornhaas v Dithmar ECLI:EU:C:2015:806.

${ }^{10}$ Ibid., at [28].
} 
Second, the Court's jurisprudence has always permitted Member States a limited power to impose restrictions, based on domestic public policy, on the exercise of Treaty freedoms. In order to avoid undermining the freedoms, such restrictions are subject to strict review by the Court. In the context of freedom of establishment, permissible restrictions must (i) be applied in a non-discriminatory manner; (ii) be justified by imperative requirements of the public interest; (iii) be effective to secure their objective; and (iv) not be disproportionate in their effect. ${ }^{11}$

Finally, we should note that, under the framework established by the European Insolvency Regulation, choice of law for insolvency proceedings is tied to choice of jurisdiction, which in turn depends on an autonomous concept known as the debtor's 'centre of main interests'. ${ }^{12}$ For a company, this will be the jurisdiction in which the debtor 'conducts the administration of its interests on a regular basis and which is ascertainable by third parties'. This may well be a different jurisdiction from that of the company's registered office. The law of the place where the proceedings are opened is then applied to govern the insolvency process, including rules prescribing the 'conditions for the opening' of insolvency proceedings and measures laying down the consequences of 'legal acts detrimental to all the creditors'. ${ }^{13}$ In Kornhaas, the Court held that this included a German law measure imposing personal liability on company directors for any payments made by the company after failure to file for insolvency proceedings within three weeks of the company becoming over-indebted, because this measure dealt with the consequences of failure to open insolvency proceedings and regulated acts detrimental to all the creditors. As a consequence, many Member States' creditor protection measures applying in the vicinity of insolvency would also be classed as 'insolvency law' measures within the ambit of the Regulation. The result is that directors and creditors of a company incorporated in one Member State may find that (depending on where its COMI is judged to have been) the rules governing directors' liability in the vicinity of insolvency in another Member State are applied instead of the laws of the place of incorporation. ${ }^{14}$

\subsection{Exercise of Corporate Freedom of Establishment}

The judicial development of corporate freedom of establishment triggered largescale reliance on foreign company laws by entrepreneurs incorporating new businesses. As demonstrated by the facts in Centros, these appear largely to have

\footnotetext{
11 Case C-55/94 Gebhard v Colsiglio dell'Ordine degli Avvocati e Procuratori di Milano [1995] ECR $\mathrm{I}-4165$.

12 Regulation (EU) 2015/848 on insolvency proceedings (recast), OJ 2015 L141/19, Article 3.

13 Ibid., Article 7.

14 This may not only confound expectations but also lead to inappropriately high (or low) levels of creditor protection. For example, if the laws of the Member State of incorporation ('State A') apply creditor protection measures that are categorised as company law, whereas the Member State in which the COMI is located ('State B') applies measures categorised as insolvency law, creditors may enjoy two tiers of protection, through the application of the company law of State A and the insolvency law of State B. However, if the allocation were reversed, such that State A governed creditor protection through insolvency law and State B through company law, it would seem at least arguable that neither set of measures might apply.
} 
been motivated by a desire to avoid minimum capital requirements in entrepreneurs' home states. The jurisdiction of choice for these entrepreneurs was frequently the UK, where no minimum capital is required for a private company. ${ }^{15}$ Studies of the UK register of companies reported a dramatic increase in the number of 'foreign' limited companies from 2003 onwards. ${ }^{16}$ The trading offices of these companies are unevenly distributed across other Member States - although Germany has by far the largest share - probably reflecting the significant differences in the cost of registering branches in the jurisdictions where they carry on business. ${ }^{17}$

The rate of such selection of company law at the formation stage appears, however, to have peaked in $2006-7$, having since fallen back somewhat. ${ }^{18}$ In part, this may be because entrepreneurs found that compliance costs under English company law were higher than expected. ${ }^{19}$ At the same time, a number of other Member States have responded to the outflow of incorporations by reducing domestic minimum capital requirements, as detailed in Table $1 .{ }^{20}$ Together, these factors reduce the net benefit to entrepreneurs of incorporating under English law.

Despite the reduction in the rate of new incorporations, there remains a very substantial total population of English companies formed by entrepreneurs in other Member States and carrying on business wholly outside the UK. In the 'host' Member State such companies are often referred to as 'pseudo-foreign': formally, they are incorporated in the UK (and so 'foreign'), but functionally, they are domestic businesses. Estimates of the population of such UK limited companies formed by entrepreneurs in selected other EU Member States are set out in Table 2. These companies were identified using register of companies data from the UK Companies House. For each year in the period 1999-2011, incorporations by entrepreneurs from other Member States were identified as newly formed UK companies for which the majority of the company's directors provided addresses located in the relevant country. ${ }^{21}$ From the annual figure were subtracted all such companies that had been removed from the register in that year. The annual net figures were then summed for the entire period to give the reported numbers. This provides a low bound on the number of UK-incorporated companies operated by

\footnotetext{
15 See Armour and Cumming (2008), at pp 312-314. The start-up costs - in terms of both time and money - associated with forming a private company in the UK are also significantly lower than in most other Member States: see, e.g., Djankov et al. (2002), at pp 18-20.

16 Armour (2005), at p 386; Becht et al. (2008), at pp 249-252. In these studies 'foreign' status is determined either by a non-English language name, or by the company's directors all residing in a country that is not the UK.

17 Becht et al. (2009).

18 Westhoff (2007); Bratton et al. (2009); Ringe (2013).

19 Bratton et al. (2009), at pp 376-377.

20 See Ringe (2010). However, cf. Ringe (2013) reporting that numbers of 'Austrian' UK Ltds have decreased at a similar rate to 'German' ones, even though Austrian minimum capital requirements have not been reduced, whereas German ones have.

21 This methodology is based on prior literature: see supra n. 16. The numbers are not significantly different if a more restrictive criterion (all directors having addresses in the relevant country) or a less restrictive criterion (any director having an address in the relevant country) is used.
} 
Table 1 Evolution of minimum capital requirements in selected EU Member States, 1999-2012

\begin{tabular}{lll}
\hline Country & Minimum capital in 1999 & Minimum capital in 2012 \\
\hline Austria & $€ 35,000$ & $€ 35,000$ \\
Belgium & $€ 18,500$ & $€ 18,500$ \\
Czech Republic & $€ 41,000^{*}$ & $€ 8,000^{*}$ \\
Estonia & $€ 25,000$ & $€ 25,000$ \\
France & $€ 7,500^{*}$ & None \\
Germany & $€ 25,000$ & None (Unternehmergesellschaft) \\
Ireland & None & None \\
Italy & $€ 10,000$ & None (Srls) \\
Latvia & $€ 2,800^{*}$ & None \\
Lithuania & $€ 2,900^{*}$ & $€ 2,900^{*}$ \\
Netherlands & $€ 18,000$ & None \\
Poland & $€ 900^{*}$ & $€ 1,200^{*}$ \\
Slovenia & $€ 6,200^{*}$ & $€ 7,500$ \\
Spain & $€ 3,000^{*}$ & $€ 3,000$ \\
Sweden & $€ 10,000^{*}$ & $€ 5,000^{*}$ \\
UK & None & None
\end{tabular}

Data are from Armour et al. (2016). Where minimum capital requirement is expressed in national currency, conversion into euros is approximate, designated by $*$.

Table 2 Estimates of the population of UK companies operated by entrepreneurs in selected other EU Member States, 2011

Dataset from UK Companies House prepared in relation to Armour and Ringe (2017)

\begin{tabular}{lc}
\hline Founder's country & Number of companies \\
\hline Austria & 3,392 \\
Czech Republic & 753 \\
Denmark & 3,948 \\
France & 12,100 \\
Germany & 61,485 \\
Italy & 6,032 \\
Netherlands & 13,988 \\
Spain & 1,607 \\
Average & 12,913 \\
Total & 103,305 \\
\hline
\end{tabular}

entrepreneurs in the relevant Member States, because it excludes companies formed before 1999 and after 2011.

The total number of companies identified in Table 2 is 103,305, an average of 12,913 for each Member State considered. If this average number is extrapolated to the 27 EU Member States other than the UK (and excluding Ireland, which never had any minimum capital requirement), this would imply a total of 335,741 such UK-incorporated companies. This is consistent with a dramatic growth in the overall 
Table 3 Total number of German branches registered in the German commercial register by UKincorporated companies, 2009-2016

\begin{tabular}{lllllllll}
\hline Year & 2009 & 2010 & 2011 & 2012 & 2013 & 2014 & 2015 & 2016 \\
\hline Registrations & 17,524 & 17,551 & 14,814 & 12,553 & 11,282 & 10,491 & 9,703 & 8,968 \\
\hline
\end{tabular}

Data collected and reported on an annual basis by Kornblum (2009-2016).

total number of companies registered in the UK, which grew from approximately 1.7 million in 1999 to nearly 3.5 million by $2015 .^{22}$

The UK limited company appears to have had the greatest popularity in Germany. ${ }^{23}$ Echoing the general trend described above, the foundation of UK limited companies erupted in the wake of the Centros case, reaching an all-time high in 2006-7. Germany has since witnessed a slow but steady decline in numbers of newly founded UKincorporated companies, for a variety of reasons. Although the relative significance of various factors is debated, many consider that an important factor in this decline was the introduction of the new 'entrepreneur company' (Unternehmergesellschaft) in 2008 , which did away with the mandatory minimum capital requirement. ${ }^{24}$

This decline is reflected in Table 3, which reports the total numbers of UKincorporated companies with a branch registered in the German commercial register, pursuant to the requirements under the Eleventh Company Law Directive. ${ }^{25}$ While it should be borne in mind when interpreting these numbers that a substantial proportion of company founders do not fulfil their duty to register a branch in Germany, the direction of trend is clear.

In sum, although there are some differences in the estimated numbers depending on the methodology employed, and the number of new incorporations has tailed off in recent years, there are, on any estimate, still a large number of UK companies established and operated by entrepreneurs based in other Member States. As we shall see, the future of these companies is foreshortened by Brexit.

\section{Will the EU Treaty Freedom of Establishment Continue to Apply to These Companies?}

Whether, and to what extent, the EU Treaty freedom of establishment will continue to apply to corporate citizens incorporated in the UK but established elsewhere in the EU will depend on the terms governing the UK's exit from the EU and its

\footnotetext{
22 UK Companies House (2015), at p 7.

23 Estimates differ according to the date and methodology employed. Westhoff (2007) estimates that the total number of UK limited companies incorporated by German entrepreneurs peaked at 46,000. However, this was measured as of 2007. In contrast, the figure for Germany in Table $2(61,485)$ includes all those incorporated up to 2011, but also subtracts 'deaths' during the period 1999-2011, to estimate the net population as of 2011 .

24 Cf. Ringe (2013), noting a similar decline in use of the UK limited company form in Austria after 2007 , but no reduction in the domestic minimum capital requirement.

25 Directive 89/666/EEC, OJ 1989 L395/36.
} 
continuing relationship with the remaining 27 Member States. Broadly speaking, the possible outcomes of this process may be grouped into three categories: (i) so-called 'soft' Brexit, with continuing participation in the single market by the UK through membership of EFTA and the EEA; (ii) so-called 'hard' Brexit: no agreement beyond continuing reliance on the WTO framework; or (iii) a bilateral agreement between the UK and the EU27. We will consider these in turn.

\subsection{Soft Brexit: UK Membership of EFTA and the EEA}

So-called 'soft Brexit' (sometimes referred to as the 'Norway model') would involve the UK remaining in the single market. There is some controversy as to whether the UK could simply leave the EU but remain in the single market by virtue of being a party to the European Economic Area (EEA), or whether the latter agreement would need to be renegotiated to accommodate the UK's new status. ${ }^{26}$ While the UK is a contracting party to the EEA Agreement, many of that Agreement's provisions are drafted such that they only apply in relation to EU and European Free Trade Association (EFTA) Member States. ${ }^{27}$ Consequently, it appears that to achieve a 'soft' Brexit it would be necessary for the text of the EEA Agreement to be revised at least to some degree, even if the UK were to re-join EFTA. $^{28}$

Membership of the EEA entails acceptance of the EU's four freedoms: goods, persons, services and capital. ${ }^{29}$ Moreover, the EEA requires contracting parties to implement, as part of their 'internal legal order', the vast majority of the EU's acquis (as set out in the 22 Annexes to the EEA Agreement), save for the Common Agricultural Policy, the Customs Union, the Common Trade Policy, the Common Foreign and Security Policy, Justice and Home Affairs, and the European Monetary Union.

If the UK pursued this route, freedom of establishment would continue to apply. Thus restrictions on the freedom of establishment of nationals of an EFTA State that is a signatory to the EEA (an 'EEA/EFTA State'), as well as EU Member States, are prohibited. ${ }^{30}$ Moreover, for these purposes, companies validly formed in accordance with the law of an EEA/EFTA State, or an EU Member State, are treated in the same way as natural persons. ${ }^{31}$ As a consequence, the case law on corporate freedom of establishment applies mutatis mutandis to companies formed in EEA/EFTA States.

\footnotetext{
26 See Schroeter and Nemeczek (2016). This Section draws on Armour (2016).

27 See, e.g., Agreement on the European Economic Area ('EEA') OJ 1994 L1/3, Article 34: 'Companies or firms formed in accordance with the law of an EC Member State or an EFTA State and having their registered office, central administration or principal place of business within the territory of the Contracting Parties shall, for the purposes of this Chapter, be treated in the same way as natural persons who are nationals of EC Member States or EFTA States.' (emphasis added).

28 This would require at least modification of Article 2(b) of the EEA Agreement, which currently defines the 'EFTA States' for the purposes of that Agreement to mean Iceland, Liechtenstein and Norway (Switzerland, which is the fourth member of EFTA, is not a party to the EEA).

29 EEA Agreement, Article 1(2).

${ }^{30}$ EEA Agreement, Article 31 (tracking Article 49 TFEU, discussed above, text to n. 1).

31 EEA Agreement, Article 34 (tracking Article 54 TFEU).
} 
In general, all EU company law legislation is designated as being 'EEA relevant', with the effect that EEA/EFTA States are obliged to enact it as part of their domestic laws. Annex XXII to the EEA Agreement, 'Company Law', sets out the list of relevant EU company law legislative measures. These encompass the principal measures (as amended by subsequent measures) set out in Table 4.

However, it is important to note that the European Insolvency Regulation was enacted pursuant to the EU's competence in relation to judicial cooperation, ${ }^{32}$ which falls within its broader competence in relation to freedom, security and justice. ${ }^{33}$ This is excluded from the EEA Agreement. Consequently the European Insolvency Regulation is not a text with EEA relevance and would no longer continue to apply to the UK were this option to be pursued.

This means that EEA members are thrown back onto their national laws regarding jurisdiction to open insolvency proceedings and the recognition of foreign insolvency proceedings. As the European Insolvency Regulation was enacted in 2000, very shortly after the Centros decision, the EU Member States have had very little experience of the application of their national laws as respects companies that have migrated across borders in reliance on their freedom of establishment. Some countries have of course enacted the UNCITRAL Model Law on Cross-Border Insolvency Law, ${ }^{34}$ which closely follows the schema of the European Insolvency Regulation, but - presumably because the Regulation itself is applicable - the Model Law has been adopted by very few EU Member States. ${ }^{35}$ Especially in the light of the recent ECJ ruling in Kornhaas that measures applicable only in the vicinity of insolvency do not constitute restrictions on the exercise of freedom of establishment, ${ }^{36}$ this in itself would pose considerable difficulties for UK-registered companies.

\subsection{Other Outcomes: Hard Brexit or Bilateral Agreement Between the UK and the EU}

In the event that the UK and the EU fail to agree terms and fail to extend the twoyear period prescribed for exit negotiations by Article 50 of the EU Treaty, the UK will exit the EU subject only to the WTO framework, to which the UK and EU are common parties. This framework does not include provisions protecting freedom of establishment for companies.

A third possible outcome would involve a bilateral arrangement between the UK and the EU. Examples of such arrangements include the bundle of bilateral measures between Switzerland and the EU, and the Comprehensive Economic and Trade Agreement (CETA) recently negotiated between the EU and Canada. None of these frameworks include provisions protecting freedom of establishment for

\footnotetext{
32 TFEU, Article 81; European Insolvency Regulation (recast), supra n. 12, Preamble para. (3).

33 TFEU, Article 4(2)(i); European Insolvency Regulation (recast), supra n. 12, Preamble para (2).

34 UNCITRAL Model Law on Cross-Border Insolvency with Guide to Enactment and Implementation (2014).

35 To date, only Greece, Poland, Romania, Slovenia and the UK have enacted the Model Law.

36 See above, text to nn. 9-10.
} 
Table 4 Principal EU company law legislative measures having EEA relevance

First Company Law Directive (Revised) 2009/101/EC, OJ 2009 L 258/11

Second Company Law Directive (Revised) 2012/30/EU, OJ 2012 L 315/74

Third Company Law Directive (Mergers, Revised) 2011/35/EU, OJ 2011 L 110/1

Fourth Company Law Directive (Accounts) 78/660/EEC, OJ 1978 L 222/11

Sixth Company Law Directive (Division) 82/891/EEC, OJ 1982 L 378/47

Seventh Company Law Directive (Consolidated Accounts) 83/349/EEC, OJ 1983 L193/1

Eleventh Company Law Directive (Branches) 89/666/EEC, OJ 1989 L 395/36

Twelfth Company Law Directive (Single-member private limited liability companies, Revised)

2009/102/EC, OJ 2009 L 258/20

EEIG Regulation (EEC) No 2137/85, OJ 1985 L 199/1

SE Regulation (EC) No 2157/2001, OJ 2001 L 294/1

International Accounting Standards Regulations (EC) No 1606/2002, OJ 2002 L 243/1, and (EC) No 1126/2008, OJ 2008 L 320/1

SCE Regulation (EC) No 1435/2003, OJ 2003 L 207/1

Takeover Directive 2004/25/EC, OJ 2004 L 142/12

Cross-Border Mergers Directive 2005/56/EC, OJ 2005 L 310/1

Audit Directive 2006/43/EC, OJ 2006 L 157/87

Shareholder Rights Directive 2007/36/EC, OJ 2007 L 184/17

Interconnection of Registers Directive 2012/17/EU, OJ 2012 L 156/1

Financial Reporting Directive 2013/34/EU, OJ 2013 L 182/19

companies. Unless the terms of any such arrangement negotiated by the UK and the EU27 are different from these (admittedly imperfect) precedents, UK corporate citizens incorporated by entrepreneurs based in other EU Member States will no longer be able to rely on freedom of establishment.

These potential outcomes pose an obvious question: what will be the legal consequence for affected corporate citizens?

\section{If the EU Freedom of Establishment Ceases to Apply, What Will Be the Legal Consequences?}

The simple answer is that when and if freedom of establishment ceases to apply, the legal consequences for 'pseudo-foreign' incorporations will revert to being determined under national principles of private international law. We therefore need to consider each of the following two questions by Member State. First, as a general rule, what is the legal treatment - from the perspective of private international law - of UK-incorporated companies operating in that Member State? Second, would this treatment be the same for companies that were incorporated prior to the date of Brexit? While this analysis should in principle be conducted for every Member State, we focus in this Section on the (rather similar) positions in Germany and Austria, where incorporation in the UK has proved a particularly attractive option for domestic entrepreneurs. 


\subsection{Application of the Real Seat Theory}

Traditionally, German and Austrian conflict of law rules for determining the applicable company law have been based on the 'real seat' theory (Sitztheorie). According to Section 10 of the Austrian Act on Private International Law (the 'PIL Act'), ${ }^{37}$ the lex societatis is determined by the location of the company's central administration. Similarly, albeit on the basis of case law, ${ }^{38}$ for Germany the main connecting factor for determining the applicable company law is the company's actual centre of administration. The requirements for valid corporate formation generally fall within the scope of the lex societatis; the lex societatis furthermore determines the legal capacity of a company and the issue of shareholder liability. ${ }^{39}$

The actual location of the centre of administration is not easy to determine. German courts have defined this centre as the place where 'the material corporate decisions of the management are implemented in day-to-day managerial decisionmaking ${ }^{40}$ Austrian courts also tend to follow that approach. ${ }^{41}$ Clearly, the place of the company's main operations - that is, the market on which it operates - is not the connecting factor as long as decisions are implemented elsewhere. Furthermore, the centre of administration is not located at the place where the material corporate decisions are taken but rather where they are implemented. This is of importance in the context of cross-border groups: even if the parent company is located abroad and all strategic decisions are taken at that level, this does not automatically affect the location of the company's central administration, provided that the day-to-day decisions are taken elsewhere. As a consequence, the crucial question is: where do the members of management meet regularly in order to take day-to-day management decisions? That place may be elusive, especially if management is not generally present at the same place but takes its decisions via electronic communication. In any case, the location of the directors' main residence may be of some importance in this respect.

In the wake of the ECJ decision in Centros and subsequent judgments on freedom of establishment, German and Austrian courts have acknowledged that this traditional approach can no longer be applied to companies incorporated in another EU or EEA Member State, especially if that jurisdiction applies some form of the incorporation theory. ${ }^{42}$ For such companies, the applicable legal rules are exclusively determined by reference to the lex societatis of the registered office: ${ }^{43}$ in our case, UK company law. Today, this encompasses all company law

\footnotetext{
${ }^{37}$ Austrian Federal Law Gazette No. 304/1978.

${ }^{38}$ German Bundesgerichtshof, Judgment of 21 March 1986, V ZR 10/85, BGHZ 97, 269; Judgment of 1 July 2002, II ZR 380/00, BGHZ 151, 204.

${ }^{39}$ See Eckert (2010), at p 232 et seq.

${ }^{40}$ German Bundesgerichtshof, Judgment of 21 March 1986, V ZR 10/85, BGHZ 97, 269.

${ }^{41}$ E.g., Austrian Oberster Gerichtshof, Judgment of 7 October 1998, 3 Ob 44/98 m; Eckert (2010), at p 30 .

${ }^{42}$ See, e.g., German Bundesgerichtshof, Judgment of 13 March 2003, VII ZR 370/98, BGHZ 154, 185; Judgment of 14 March 2005, II ZR 5/03, ZIP 2005, 806; Austrian Oberster Gerichtshof, Judgment of 15 July 1999, 6 Ob 124/99z; Judgment of 8 May 2008, 6 Ob 232/07x.

43 Austrian Oberster Gerichtshof, Judgment of 29 April 2004, 6 Ob 43/04y.
} 
questions. ${ }^{44}$ This helps to avoid a melange of different (and quite possibly incompatible) company law rules applying to different issues, ${ }^{45}$ but of course raises difficult questions regarding the boundaries between company law and other areas of law.

In relation to companies incorporated in non-EU/EEA countries, however, the lex societatis of the location of the company's central administration continues to apply. For Austria, the statutory provision in Section 10 PIL Act makes any discussion moot. Due to the lack of a statutory rule, this does not go completely unchallenged in German academic discourse, ${ }^{46}$ but for practical purposes can be taken for granted. The leading precedent is the Trabrennbahn case of the German Federal Court of Justice from 2008. ${ }^{47}$ This dealt with a Swiss stock corporation that transferred its central administration from Switzerland to Germany. The Court was asked to decide whether to extend the incorporation theory to companies outside the EU and the EEA: the exact situation UK companies would face in a 'hard Brexit' scenario. The Federal Court of Justice, however, did not take this path, choosing instead to remain with the traditional real seat theory. Companies registered in Liechtenstein, which is a member of the EEA, on the other hand, benefit from the freedom of establishment, as explained in a previous case of the German Federal Court of Justice from 2005 . $^{48}$

In practice this means the following: if a company is incorporated in a non-EU/ EEA country, which follows the theory of incorporation, it will be recognised by the courts of that country, irrespective of the location of its central administration. If the company's central administration were located in Germany or Austria, however, German or Austrian courts would not apply the company law of the country of incorporation, but their own company law. As we shall see, this would have very serious consequences for UK companies.

Under both German and Austrian company law, companies (both $\mathrm{GmbH}$ and AG) have to be registered locally in order to obtain legal personality; registration in the country of incorporation is insufficient. Thus, applying their own company law, German and Austrian courts will arrive at the result that the entity is not a company at all, but merely some type of partnership. ${ }^{49}$ While the details vary, ${ }^{50}$ in both jurisdictions the members are exposed to one dramatic consequence: they will be personally liable for the debts of their "company'

\footnotetext{
44 Ibid; ; see also Judgment of 10 September 1992, 8 Ob 14/92; Eckert (2010), at p 236 et seq.

45 Eckert (2010), at p 243.

46 See Ringe (2015), at p 164 et seq.

47 German Bundesgerichtshof, Judgment of 20 October 2008, II ZR 158/06, BGHZ 178, 192.

48 See German Bundesgerichtshof, Judgment of 19 September 2005, II ZR 158/06, BGHZ 164, 148, citing Article 31 of the EEA Agreement.

49 German Bundesgerichtshof, Judgment of 1 July 2002, II ZR 380/00 BGHZ 151, 204. For Austria, this has not been clarified by court decisions, but is the predominant opinion; see, however, Eckert and Schopper (2014), at $\S \S 107-114$ para. 15.

${ }^{50}$ Under German law the partnership may be either a commercial or a civil law partnership (see German Bundesgerichtshof, Judgment of 1 July 2002, II ZR 380/00 BGHZ 151, 204), while in Austria it can only be a civil law partnership, as commercial partnerships have to be registered locally as well.

51 German Commercial Code (HGB), Section 128, for commercial partnerships (for civil law partnerships the provision is applied by analogy); Austrian General Civil Code, Section 1199(1).
} 
the non-EU/EEA country as a company form with limited liability. That, of course, is a strong deterrent for incorporating in that country in the first place.

Presumably, this result is designed to protect local creditors against dangers posed by such 'pseudo-foreign' companies. However, the robust application of the seat theory may not even achieve this in some circumstances. For example, under Austrian law, ${ }^{52}$ the civil law partnership does not have legal personality and consequently cannot be party to legal proceedings. As a consequence, if creditors seek to sue a pseudo-foreign corporation, as opposed to suing its 'partners' directly, their claims will have to be dismissed. This has happened in practice, ${ }^{53}$ and results in adverse cost consequences; moreover, bringing the claim with the correct defendants may be barred by the statute of limitations.

Applying these principles to a hard Brexit situation would result in the following: German and Austrian courts currently do not apply their local versions of the real seat theory because of the freedom of establishment as interpreted by the CJEU. Once that freedom is no longer applicable to companies formed in the UK, the general rules of private international law will once again apply.

First, that means that members of pseudo-foreign companies newly incorporated in the UK, but with their real seat in Germany or Austria, will not be protected against liability for the company's debts. Second, and more pertinent to the issue at hand, these principles will presumably also apply to companies registered in the UK before Brexit. That, of course, has the ghastly consequence that members will lose the protection against liability provided for by the UK Companies Act, on which they relied when incorporating.

\subsection{Would Matters Be Different for Pre-Brexit UK Incorporations?}

Of course, there is one major difference between a hard Brexit scenario and other cases of application of the real seat theory. Generally, the harsh consequences of the application of local company law to pseudo-foreign companies are due to actions by the founders or members. Either they incorporated in a non-EU/EEA country with the real seat in Germany or Austria in the first place, or they moved the real seat at some stage after incorporation into these countries; in either case, they should have known about the legal consequences of their actions. With pre-Brexit incorporations, however, incorporation in the UK was protected by the freedom of establishment at that time, even if the company's central administration was in Germany or Austria; only due to a later change of the legal regime applicable to the UK and, therefore, due to events the members could not control, the protection will be lost.

In the light of these circumstances, an academic debate has sprung up in Germany, seeking to avoid the harsh consequences of personal liability for shareholders of companies founded pre-Brexit. The proposed solution is to protect pre-Brexit companies (Altgesellschaften) through a doctrine of entitlements or vested rights under

\footnotetext{
52 Austrian General Civil Code, Section 1175(2). The position is different in Germany, where commercial partnerships (German Commercial Code, Section 124) and civil law partnerships (German Bundesgerichtshof, Judgment of 29 January 2001, II ZR 331/00 BGHZ 146, 341) can be parties to legal proceedings.

53 Austrian Oberster Gerichtshof, Judgment of 23 August 2000, 3 Ob 59/00y.
} 
German international private law. ${ }^{54}$ Applying general principles of intertemporal law, German law would then continue to recognise such entities as UK companies, even after Brexit. ${ }^{55}$ A similar result might be reached by invoking the principle of protection of legitimate expectations firmly embedded in German constitutional law, ${ }^{56}$ although recent discussion is dismissive of such arguments. ${ }^{57}$ It has also been argued that any extension of liability will be limited to new debts incurred after Brexit (or after the date of the UK's Article 50 notification), while pre-existing liabilities will not affect shareholders directly. ${ }^{58}$ Of course, creative application of substantive company law rules might further mitigate the effects of application of the real seat theory. ${ }^{59}$ Nevertheless, as long as the issue is not clarified by the legislator or the courts, ${ }^{60}$ one has to assume that the members of pseudo-foreign companies registered in the UK but with their central administration in Germany or Austria may well become personally liable for their company's debts. Therefore, it may be advisable to convert pseudo-foreign companies into local companies before Brexit. ${ }^{61}$

Similar issues may exist in other Member States that apply versions of the real seat theory, such as Belgium or France. However, the precise consequences of Brexit for pseudo-foreign companies can only be determined by analysing substantive company law, which we cannot achieve in this paper. Additionally, comparable issues may also exist for Member States following the incorporation theory. For example, under Dutch law, pseudo-foreign companies are recognised even if they are incorporated outside of the European Union; however, they are subject to a legal regime imposing additional requirements, which, to a significant extent, are equivalent to Dutch company law. ${ }^{62}$

\section{What Will Happen to Companies Undergoing a Cross-Border Transition?}

Up to this point, we have focused on the position of UK companies that have relied on the freedom of establishment from their moment of formation. However, EU law has also - to date, to a lesser degree - facilitated corporate mobility for pre-

\footnotetext{
54 See Freitag and Korch (2016), at p 1363 et seq.; Lehmann and Zetzsche (2017); Weller et al. (2016), at pp 2381-2382; see also Lehmann and Zetzsche (2016), at p 1013 et seq.

55 See Freitag and Korch (2016), at p 1363; Weller et al. (2016), at p 2382 (intertemporal principle of lex temporis actus).

56 See Bayer and Schmidt (2016), at p 1933.

57 See Seeger (2016).

58 Freitag and Korch (2016); Schall (2016), at p 413.

59 See especially Eckert (2010), at p 513 et seq. (on pseudo-foreign companies generally).

${ }^{60}$ Rejecting any mitigation as unwarranted, see, e.g., Seeger (2016), at p 1819 et seq.; Seggewiße and Weber (2016), at p 1302 et seq.

61 See Schall (2016), at p 414 et seq.; Seeger (2016), at p 1821 et seq. (both discussing possible options, ranging from an asset deal to a cross-border conversion and a cross-border merger).

62 See Law of 17 December 1997, Netherlands Official Journal ('Staatsblad') 1997, 697, as amended by the law of 18 June 2012, Staatsblad 2012, 300. The application of this Law to pseudo-foreign companies with the registered seat in another Member State was the central issue in Case C-167/01 Kamer van Koophandel en Fabrieken voor Amsterdam v Inspire Art Ltd [2003] ECR I-10155; cf. de Kluiver (2004).
} 
established companies. This has principally been achieved through the frameworks established by the Cross-Border Mergers Directive and in respect of the European Public Company, or Societas Europaea. Where these frameworks have successfully been used to effect a change in applicable company law, the results may also fall to be analysed under the principles discussed in Sect. 4. However, the reliance on EU law to effect such changes raises further Brexit-related questions: what will happen to firms that are caught part way through such a transition at the time of Brexit? In the event of a 'soft' Brexit, the answer is straightforward: there would be no change, as the relevant governing legislation all has EEA relevance. ${ }^{63}$ However, in the event of a 'hard' Brexit, matters would be rather more complicated.

\subsection{Cross-Border Mergers}

Limited liability companies formed in accordance with the law of a Member State and which have their registered office, central administration or principal place of business in the EU may merge with other such companies pursuant to national legislation that gives effect to the Cross-Border Mergers Directive. ${ }^{64}$ A 2013 study prepared for the European Commission concluded that the Directive had 'ushered in a new age for cross-border mergers'. ${ }^{65}$ Before its transposition into domestic law, more than half of the EU/EEA Member States did not have procedures for crossborder mergers. Over the four years following the Directive's implementation date in December 2007, the annual numbers of cross-border mergers within the EU more than doubled, with 361 such transactions, for example, occurring in 2012.

The Directive sets out various requirements that must be followed for a crossborder merger. These include a requirement for the merging companies to draw up common draft terms of cross-border merger, a report of the management or administrative body, an independent expert report, and approval by the general meeting of each merging company. ${ }^{66}$ Each Member State must designate the court, notary or other authority which has to scrutinise the legality of the cross-border merger as regards that part of the procedure that concerns the merging company subject to its law. ${ }^{67}$ The authority must issue a certificate conclusively attesting to the proper completion of the pre-merger acts and formalities 'without delay'. Each Member State must also designate the court, notary or other authority which has to scrutinise the legality of the completion of the cross-border merger and, where appropriate, of the formation of a new company resulting from the cross-border merger if the company created by the cross-border merger is subject to its national law. ${ }^{68}$ Each merging company must submit the certificate issued by its own national authority to the body responsible for dealing with the completion of the cross-border

\footnotetext{
63 See above, text to nn. 30-31.

64 Directive 2005/56/EC of the European Parliament and of the Council on cross-border mergers of limited liability companies, OJ 2005 L310/1.

65 Bech-Bruun/Lexidale (2013), at pp 5-7.

66 Directive 2005/56/EC, Articles 5-9.

67 Ibid., Article 10.

68 Ibid., Article 11.
} 
merger within six months of the certificate being issued. The law of the Member State to whose jurisdiction the resulting company is subject determines the date on which the cross-border merger takes effect. ${ }^{69}$ This date must be after the relevant authority has scrutinised the merger.

The Directive sets out the consequences of the cross-border merger from the date on which the cross-border merger takes effect. ${ }^{70}$ These include that the assets and liabilities of the company being acquired are transferred to the acquiring company, that members of that company become members of the acquiring company and that the company being acquired ceases to exist. Where there are special formalities to be carried out to transfer certain assets, rights and obligations, the company resulting from the cross-border merger must carry these out.

In practice, the Member State authorities responsible for issuing a certificate attesting to the proper completion of the pre-merger acts and formalities do not always issue these without delay. It may also be difficult to predict how long the authority responsible for dealing with the completion of the merger will take to complete the scrutiny of this aspect. The result of this could be that companies who have completed all the necessary steps they are required to take and have submitted all the necessary information to the relevant authorities may find themselves in a position where the relevant authorities have not finished scrutinising the merger before the date on which the UK ceases to be a member of the EU/EEA.

The Directive does not contemplate what is to happen in such a case, and it seems unlikely that the national laws implementing the Directive will have provisions to deal with that either. The Companies (Cross-Border Mergers) Regulations 2007, ${ }^{71}$ which are the UK regulations that implement the Directive, provide that the court may make an order approving the completion of the cross-border merger if certain conditions are satisfied. ${ }^{72}$ If the court approves the completion it must fix a date, not less than 21 days after the date of the order, on which the consequences of the merger are to have effect. The Regulations set out the consequences of the merger, following the provisions of the Directive, and provide that the transferee company must take such steps as are required by law (including by the law of another EEA State) for the transfer of the assets and liabilities of the transferor companies to be effective in relation to other persons.

\footnotetext{
69 Ibid., Article 12.

70 Ibid., Article 14.

71 SI 2007/2974.

72 These are that: (a) the transferee company is a UK company; (b) an order has been made under Regulation 6 of the Regulations (court approval of pre-merger requirements) in relation to each UK merging company; (c) an order has been made by a competent authority of another EEA State for the purposes of Article 10.2 of the Directive (issue of pre-merger certificate) in relation to each merging company which is an EEA company; (d) the application is made to the court on a date not more than 6 months after the making of any order referred to in sub-paragraph (b) or (c); (e) the draft terms of merger approved by every order referred to in sub-paragraphs (b) and (c) are the same; and (f) where appropriate, any arrangements for employee participation in the transferee company have been determined in accordance with Part 4 of the Regulations (employee participation).
} 
Assuming that the Regulations remain in force and are not repealed when the UK ceases to be a member of the EU/EEA, ${ }^{73}$ it therefore seems that if a UK court makes an order approving the completion of a cross-border merger where the relevant conditions have been satisfied, the cross-border merger will be completed in accordance with the Regulations on the date stated in the order even if this falls after the date on which the UK ceases to be a member of the EU/EEA.

If the company surviving a cross-border merger that involves a UK company will be subject to the jurisdiction of another Member State and the UK ceases to be a member of the EU/EEA before the cross-border merger has taken effect, it seems that whether it will be possible to complete the cross-border merger after the UK ceases to be a member of the EU/EEA will depend on an interpretation of the relevant implementing legislation in the Member State of the surviving company. For example, the Austrian implementing legislation defines 'companies' that may merge across borders as those covered by Article 1 of Directive 2009/101/EC, which includes UK companies with limited liability. Even though the wording of Article 1 may not change immediately upon Brexit, Section 3 of the Austrian Act on Cross-Border Mergers clearly states that Austrian companies may merge with such companies if they are incorporated according to the law of another EU/EEA Member State. Once Brexit takes place, UK companies will presumably no longer be covered by the wording, which seems to envisage Member State status at the time of the merger and not simply at the time of formation. In such a situation, it seems that the merger would not be entered into the Austrian register and therefore not become effective. Sections 122a and 122b of the German Transformation Act arguably mandate the same result.

In order to mitigate such problems, it would be helpful if Member States were to agree expressly that, where companies have submitted the relevant documents to the relevant authority scrutinising completion of the cross-border merger before the date on which the UK ceases to be a member of the EU/EEA, the relevant authority may make an order in relation to the completion of the merger after the date when the UK ceases to be a member of the EU/EEA.

The Directive requires Member States' laws to publicise the completion of the crossborder merger in the Member State of the surviving company. The registry of the surviving company must notify other registries where the merging companies were required to file documents that the cross-border merger has taken effect 'without delay'. ${ }^{74}$ The UK Regulations implementing the Directive require a UK surviving company to file a copy of the court order with the Registrar of Companies within seven days of the court order approving the merger. Provided the UK Regulations are not repealed, this obligation will continue to apply, even if the UK has ceased to be a member

\footnotetext{
73 However, the Regulations will be repealed if the European Communities Act 1972 is repealed without some provision to preserve the Regulations. There are various possible 'preservation' scenarios, including: (i) the UK withdraws as a Member State but the Regulations remain in place because the ECA has not been repealed yet; (ii) the UK withdraws as a Member State but the Regulations remain in place because the ECA has been repealed with some saving for provisions enacted under Section 2(2) (which includes the Regulations). If the ECA is repealed and there is no saving provision for the Regulations and no transitional provisions, it is unclear what the position will be for companies that started the process. However, current indications of UK government policy in favour of a general 'preservation' Bill consequent upon withdrawal suggest that this is unlikely to be the case.

74 Directive 2005/56/EC, Article 13.
} 
of the EU/EEA. The UK Regulations also require the UK Registrar of Companies to notify other relevant authorities without 'undue delay'. Again, this obligation should continue to apply provided the UK Regulations are not repealed. If the UK Registrar of Companies receives a notification from the registry of an EEA State of an order approving the completion of a cross-border merger, he must strike the relevant UK merging company's (or companies') name from the UK register on the date the merger takes effect or without undue delay afterwards and add a note to the register that the assets and liabilities have been transferred to the surviving company. Again, this obligation should continue to apply provided the UK Regulations are not repealed.

Where a company resulting from a cross-border merger is operating under an employee participation system, that company must take measures to ensure that employees' participation rights are protected if there are subsequent domestic mergers in the three years after the cross-border merger has taken effect. ${ }^{75}$ Under Article 40 of the UK Regulations that implement the Directive, this obligation is implemented and will continue to provide protection for such rights after the UK ceases to be a member of the EU/EEA.

The Cross-Border Mergers Directive has provided a basis for cross-border mergers of certain EU companies, which has been well used in practice. Member States and the UK might want to consider whether their national law already allows cross-border mergers for companies from outside the EU which follow a regime that provides equivalent protections to those provided by the Directive, and if it does not, whether to enact such a law to continue to facilitate such cross-border mergers.

\subsection{European Public Companies}

Similar issues arise in relation to companies formed as European Public Companies (SEs) pursuant to the SE Regulation. ${ }^{76}$ These companies are governed by the SE Regulation (which has direct effect), national law implementing the SE Directive, ${ }^{77}$ the SE's statutes, and the national law applying to public limited companies in the Member State in which it is registered. As of July 2016, there were 53 SEs registered in the $\mathrm{UK}^{78}$

The formation of an SE is governed by the law applicable to public limited liability companies in the Member State in which the SE establishes its registered office. $^{79}$ It acquires legal personality on the date on which it is registered in the

\footnotetext{
75 Ibid., Article 16(7).

76 Council Regulation (EC) No 2157/2001 on the Statute for a European Company, OJ 2001 L 294/1.

77 Directive 2001/86/EC supplementing the SE Regulation with regard to the involvement of employees, OJ 2001 L 294/22.

78 Companies House (2016), at Table D3.

79 Regulation 2157/2001, Article 15. Under the SE Regulation, an SE can be established in any of the following ways: (a) by the merger of two or more existing public limited companies from at least two different Member States; (b) by the formation of a holding company promoted by public or private limited companies from at least two different Member States; (c) by the formation of a subsidiary SE by companies from at least two different Member States; (d) by the conversion of a public limited company which has had, for at least two years, a subsidiary in another Member State; and (e) by the formation of a subsidiary SE where an SE is the parent (Article 2).
} 
register of the relevant Member State. ${ }^{80}$ This seems to mean that it will only be possible to form a UK SE before the date on which the UK ceases to be a member of the EU/EEA. On that date, the SE Regulation will cease to have direct effect as a matter of UK law and so (assuming no law is put in place to replicate the effect of the SE Regulation) there will no longer be any basis on which a UK SE can be formed. The Regulation provides what is to happen if acts have been performed in an SE's name before it is registered if the SE does not assume the obligations arising out of such acts after its registration. ${ }^{81}$ However, this will not apply to acts performed in an SE's name before registration if the SE is, in fact, never registered because the UK ceases to be a member of the EU/EEA.

For UK SEs formed before the date the UK ceases to be a member of the EU/ EEA, if nothing is done to replicate all or part of the SE Regulation as part of UK law, the legislation that governs UK SEs will cease to apply. ${ }^{82}$ This would leave their position very unclear and would seem highly undesirable. The Regulation states that only SEs may include the abbreviation SE in their name (subject to an exception to protect entities which used the SE abbreviation before the Regulation came into force). ${ }^{83}$ This restriction will no longer apply to UK companies following a hard Brexit, unless there is an agreement that it should continue to apply. It may, however, be unattractive for UK SEs to continue to use the SE name when this would be likely to cause confusion.

An SE may transfer its registered office to another Member State without winding up or creating a new legal person. Article 8 of the SE Regulation sets out the steps to be followed by an SE wishing to do this. The process includes drawing up a transfer proposal and a management or administrative body report explaining and justifying the legal and economic aspects of the transfer and explaining the implications of the transfer for shareholders, creditors and employees, and holding a general meeting to approve the transfer. The Member State where the SE has its registered office must appoint a court, notary or other competent authority to issue a certificate attesting to the completion of the acts and formalities to be accomplished before the transfer takes place. The transfer of an SE's registered office and the consequent amendment of its statutes take effect on the date on which the SE's new registered office is recorded in the appropriate register. An SE may not be registered unless the requirements relating to employee participation have been complied with. The SE Regulation does not contain any provisions as to the time within which the relevant authorities must issue the certificate confirming that the pre-transfer requirements have been met or must register the SE's new registered office where it has completed all the relevant steps to transfer its registered office. The SE Regulation also requires publication of documents and particulars about an SE in accordance with the national laws of the Member State where it has its registered

\footnotetext{
80 Ibid., Article 16.

81 Ibid., Article 16(2).

82 European Public Limited-Liability Company Regulations 2004, SI 2004/2326, as amended by European Public Limited-Liability Company (Amendment) Regulations 2009, SI 2009/2400, and European Public Limited-Liability Company (Amendment) Regulations 2014, SI 2014/2382.

83 Regulation 2157/2001, Article 11(2).
} 
office and in the Official Journal of the EU. However, these publicity requirements will also cease to apply to UK SEs once the UK ceases to be a member of the EU/ EEA.

Unlike the position for cross-border mergers, because there is no legislation in the UK relating to this process to transfer the registered office, it seems that if an SE has not been registered in the UK register of companies before the UK ceases to be a member of the EU, an SE from another Member State will not be able to complete its transfer process from that date onwards. For UK SEs which have completed the relevant steps to be taken by them to transfer their office to another Member State but where the relevant authority has not registered their registered office in the relevant Member State register, the position is less clear as to whether the relevant Member State could still register the company in the relevant registry (on the basis that the UK was a Member State at the date the relevant steps taken by the company were completed). It seems that there is a real risk that the relevant authority will conclude that it should not register the new registered office in the register and so the transfer process cannot complete. Again, it would be helpful if Member States were to agree expressly that, where a UK SE has submitted the relevant documents to the relevant authority scrutinising completion of the transfer of the registered office before the date on which the UK ceases to be a member of the EU/EEA, the relevant authority may make an order in relation to the completion of the transfer of the registered office after the date when the UK ceases to be a member of the EU/ EEA. It would also be helpful for the UK government to provide UK legislation to govern UK SEs or, alternatively, to require them to convert to public limited liability companies subject to UK law.

\section{Conclusion: The Implications of Brexit for EU Corporate Citizens}

As we have seen, there are possibly as many as 330,000, and on any estimate a large number, of UK companies established and operated by entrepreneurs based in other Member States. Even following the least disruptive version of Brexit - so-called 'soft' Brexit in which the UK remains part of the single market via the EEA - such companies will face considerable uncertainty regarding the resolution of their insolvency. This is because the European Insolvency Regulation would no longer be applicable, and the ECJ in Kornhaas ruled recently that measures applicable only in the vicinity of insolvency do not constitute restrictions on the exercise of freedom of establishment. ${ }^{84}$ However, 'soft' Brexit would otherwise preserve the efficacy of European company law measures and the availability of freedom of establishment to UK companies.

If the outcome is instead 'hard' Brexit whereby the UK is no longer a participant in the single market, the acquis of EU company law will no longer be applicable as such to the UK. While the UK could replicate the effects of EU law within its territory through domestic enactments, UK companies would no longer be able to avail themselves of the freedom of establishment in EU/EEA Member States.

\footnotetext{
${ }^{84}$ See above, text to nn. 9-10.
} 
Absent changes in the application of choice of law rules by other Member States, this will result in denial of limited liability for owners of UK companies operated in 'real seat' countries. This will extend at the very least to such companies founded after Brexit, but on a mechanical application of the rules could easily apply to such companies already in existence. The application of the real seat theory would be unlikely to have been priced (fully) into pre-existing credit agreements, thus resulting in a windfall to creditors and a cost for founders. Hard Brexit could also trigger catastrophic consequences for partly completed cross-border mergers or transitions to European public companies.

For those managing potentially affected companies, this analysis has clear implications. The sheer extent of the potential costs means that without a clear indication that worst-case outcomes will be avoided, prudent risk management will dictate taking considerable evasive action. For UK companies operated wholly or primarily in real seat jurisdictions, this would likely mean changing form to a domestic entity or possibly using a cross-border merger to move to another Member State which will still benefit from the freedom of establishment. And for parties considering a cross-border merger or SE conversion, this implies avoiding any such transaction with a UK company where there is any possibility the transaction will not be concluded prior to the UK's departure from the EU. In practice this is likely to have a chilling effect on such transactions during the UK's Article 50 negotiation period. ${ }^{85}$

The costs of such evasive actions, and of worst-case outcomes for companies and their founders who fail to take such actions, are likely to be significant. For UK companies operating in real seat jurisdictions, the costs will fall disproportionately on younger and smaller companies. Given that small businesses are commonly thought by policymakers to be a crucial mechanism for economic growth, this seems clearly undesirable as a matter of economic policy for such countries. At the same time, the UK will lose both the modest stream of professional services revenue associated with advice in relation to such companies, and the prospect of wider influence on the development of European company law through the widespread adoption of its corporate forms. While the UK will probably be the principal loser from uncertainty surrounding the completion of cross-border corporate transitions, which may well simply proceed without its firms, this will also have adverse consequences for EU27 Member States whose companies would have benefited from such transactions.

Both the UK and EU27 jurisdictions thus have clear potential to gain from taking steps to avoid worst-case outcomes. Such steps could consist of unilateral actions and/or bilateral measures agreed as part of the UK's 'exit agreement'. Unilateral action by real seat jurisdictions could be the simplest way to avoid the disastrous consequence of denial of limited liability for owners of pre-Brexit companies. The sooner this can be clarified by legislation, the less will be the avoidance costs that

\footnotetext{
85 The effect will probably be compounded by the fact that the precise end of the negotiation period is hard to specify with certainty. While it is widely expected that the UK's negotiation will make use of the full two years available, it is legally possible for the UK to leave the EU less than two years from triggering Article 50, by mutual agreement (TFEU Article 50(3)), or for the negotiation period to be extended with the consent of the European Council.
} 
need be incurred by such countries' entrepreneurs. At the same time, unilateral action by the UK to enact into domestic law the EU law frameworks for crossborder mergers and SEs will ensure the continued viability of UK SEs and the successful UK execution of partially completed cross-border corporate transitions where a UK entity is the desired outcome.

However, unilateral action can only go so far to ensure the completion of crossborder transitions. It seems clear that for this, some form of EU/UK agreement needs to be reached. At the very least, it is desirable to achieve agreement that where companies have submitted relevant documents to the authority scrutinising completion of a cross-border merger, creation of an SE, or transition of an SE's registered office prior to the UK's cessation of EU/EEA membership, that authority may still make an order regarding the completion of the corporate transition after the UK's membership ceases. This would avoid chilling effects on transactions during the Article 50 period. More ambitiously, EU27 Member States and the UK might want to consider whether their national law already allows cross-border mergers for companies from outside the EU which follow a regime that provides equivalent protections to those provided by the Directive and, if it does not, whether to enact such a law to continue to facilitate such cross-border mergers. This would facilitate the continued mutual benefits of cross-border transactions after completion of Brexit.

It would also be possible in principle to negotiate one or more bilateral agreements, whether with the EU or individual Member States, to avoid the adverse consequences of Brexit for such UK companies operated in real seat jurisdictions. A possible precedent could be the 1956 bilateral US-German Treaty of Friendship, Commerce and Navigation, which provides that ${ }^{86}$

'[c]ompanies constituted under the applicable laws and regulations within the territories of either Party shall be deemed companies thereof and shall have their juridical status recognized within the territories of the other Party.'

Even in the absence of political considerations clouding negotiations, this could prove problematic given the differing positions taken by other EU27 Member States. For example, the 1928 US-Austria Friendship, Commerce and Consular Rights Treaty ${ }^{87}$ only recognises US companies if they maintain a 'central office' within the US, ${ }^{88}$ a formula highly redolent of the real seat theory. ${ }^{89}$ More fundamentally, there would seem to be little interest amongst EU27 Member States in keeping open the possibility for local entrepreneurs of incorporating under UK law after Brexit. And more modest bilateral arrangements, encompassing protection

\footnotetext{
86 Treaty of Friendship, Commerce and Navigation between the Federal Republic of Germany and the United States of America, German BGB1. II 1956, 488 (English version available at http://tcc.export.gov/ Trade_Agreements/All_Trade_Agreements/exp_005344.asp), Article XXV(5). There is however still (some) discussion whether there must be a genuine link between the company and the US. Cf. Ringe (2015), at p 151 et seq.

87 Austrian Federal Law Gazette No. 192/1931 (English version available at http://tcc.export.gov/trade_ agreements/all_trade_agreements/exp_002773.asp).

88 Ibid., Article 9.

${ }^{89}$ See Schneeweiss (2014), at p 453.
} 
for existing companies, would seem to lack a clear impetus for the UK to pursue, given that the costs will likely fall on real seat jurisdictions, which themselves can readily avoid these consequences by unilateral measures.

In sum: Brexit will have significant adverse consequences for EU corporate citizens. Potentially affected companies will be well-advised - and indeed may be expected - to take steps to mitigate these consequences. For UK companies operating in real seat jurisdictions, the costs of such evasive action, and of worstcase outcomes eventuating, can most straightforwardly be avoided by modification of conflict of law rules in the real seat jurisdictions in question. For cross-border mergers and SE transactions, some sort of EU/UK agreement is necessary to ensure at the least that transactions are not chilled during the Article 50 negotiation period, and ideally, that continuity of cross-border transactions may be preserved postBrexit.

Open Access This article is distributed under the terms of the Creative Commons Attribution 4.0 International License (http://creativecommons.org/licenses/by/4.0/), which permits unrestricted use, distribution, and reproduction in any medium, provided you give appropriate credit to the original author(s) and the source, provide a link to the Creative Commons license, and indicate if changes were made.

\section{References}

Armour J (2005) Who should make corporate law? EC legislation versus regulatory competition. Curr Legal Probl 58:369-413

Armour J (2016) Brexit to the European Economic Area: what would it mean? Oxford Business Law Blog, 19 July 2016. https://www.law.ox.ac.uk/business-law-blog/blog/2016/07/brexit-europeaneconomic-area-what-would-it-mean

Armour J, Cumming DC (2008) Bankruptcy law and entrepreneurship. Am Law Econ Rev 10:303-350

Armour J, Ringe WG (2011) European company law 1999-2010: renaissance and crisis. Common Mark Law Rev 48:125-174

Armour J, Ringe WG (2017) Law and entrepreneurship in Europe. Working Paper, University of Oxford Armour J, Deakin S, Siems M (2016) CBR Extended Creditor Protection Index 1990-2013. Cambridge Centre for Business Research. https://www.repository.cam.ac.uk/handle/1810/256566

Bayer W, Schmidt J (2016) BB-Gesetzgebungs- und Rechtsprechungsreport Europäisches Unternehmensrecht 2015/2016. Betriebs-Berater 71:1923-1933

Bech-Bruun/Lexidale (2013) Study on the application of the Cross-Border Mergers Directive. http://ec. europa.eu/internal_market/company/docs/mergers/131007_study-cross-border-merger-directive_en. pdf

Becht M, Mayer C, Wagner H (2008) Where do firms incorporate? Deregulation and the cost of entry. J Corp Finance 14:241-256

Becht M, Enriques L, Korom V (2009) Centros and the cost of branching. J Corp Law Stud 9:171-199

Bratton WW, McCahery JA, Vermeulen EPM (2009) How does corporate mobility affect lawmaking? A comparative analysis. Am J Comp Law 57:347-385

Companies House (2016) Companies Register Activities 2015-16. https:/www.gov.uk/government/uploads/ system/uploads/attachment_data/file/548204/Company_Register_Activities_in_the_United_Kingdom_ 2015-16.xlsx

de Kluiver HJ (2004) Inspiring a new European company law. Eur Co Financial Law Rev 1:121-134

Djankov S, La Porta R, Lopez-de-Silanes F, Shleifer A (2002) The regulation of entry. Q J Econ 67:1-37

Eckert G (2010) Internationales Gesellschaftsrecht. Manz, Vienna

Eckert G, Schopper A (2014) Commentary to §§ 107-114. In: Torggler U (ed) GmbHG. Manz, Vienna

Freitag R, Korch S (2016) Gedanken zum Brexit-Mögliche Auswirkungen im Internationalen Gesellschaftsrecht. Zeitschrift für Wirtschaftsrecht 37:1361-1367 
Kornblum U (2009-2016) Bundesweite Rechtstatsachen zum Unternehmens-und Gesellschaftsrecht. GmbH-Rundschau 100 (2009):1056-1064; GmbH-Rundschau (2010) 101:739-748; GmbH-Rundschau (2011) 102:692-699; GmbH-Rundschau (2012) 103:728-735; GmbH-Rundschau (2013) 104:693-703; GmbH-Rundschau (2014) 105:694-703; GmbH-Rundschau (2015) 106:687-696; GmbH-Rundschau (2016) 107:691-701

Kraakman R, Armour J, Davies P, Enriques L, Hansmann H, Hertig G, Hopt K, Kanda H, Pargendler M, Ringe WG, Rock E (2017) The anatomy of corporate law, 3rd edn. OUP, Oxford

Lehmann M, Zetzsche D (2016) Brexit and the consequences for commercial and financial relations between the EU and the UK. Eur Bus Law Rev 27:999-1027

Lehmann M, Zetzsche D (2017) Die Auswirkungen des Brexit auf das Zivil- und Wirtschaftsrecht. Juristenzeitung 72:62-71

Ringe WG (2010) Sparking regulatory competition in European company law - the impact of the Centros line of case-law and its concept of 'abuse of law'. In: de la Feria R, Vogenauer S (eds) Prohibition of abuse of law: a new general principle of EU law. Hart Publishing, Oxford

Ringe WG (2013) Corporate mobility in the European Union-a flash in the pan? An empirical study on the success of lawmaking and regulatory competition. Eur Co Financial Law Rev 10:230-267

Ringe WG (2015) Internationales Gesellschaftsrecht. In: Schmidt K, Lutter M (eds) Aktiengesetz, 3rd edn. Otto Schmidt, Cologne

Schall A (2016) Grenzüberschreitende Umwandlung der Limited (UK) mit deutschem VerwaltungssitzOptionen für den Fall des Brexit. Zeitschrift für die gesamte Privatrechtswissenschaft 2:407-447

Schneeweiss H (2014) US-amerikanische LLC als Alternative zur österreichischen GmbH? Zeitschrift für Gesellschaftsrecht und angrenzendes Steuerrecht 450-455

Schroeter UG, Nemeczek H (2016) The (uncertain) impact of Brexit on the United Kingdom's membership in the European Economic Area. Eur Bus Law Rev 27:921-958

Seeger M (2016) Die Folgen des Brexit für die britische Limited mit Verwaltungssitz in Deutschland. Deutsches Steuerrecht 54:1817-1824

Seggewiße O, Weber A (2016) Auswirkungen eines britischen Austritts aus der Europäischen Union auf die in Deutschland tätigen Limiteds. GmbH-Rundschau 107:1302-1304

UK Companies House (2015) Statistical Release: Companies Register Activities 2014/15. https://www. gov.uk/government/uploads/system/uploads/attachment_data/file/456824/Incorporated_Companies_ in_the_UK_2014_15_P1-7.pdf

Weller MP, Thomale C, Benz M (2016) Englische Gesellschaften und Unternehmensinsolvenzen in der Post-Brexit-EU. Neue Juristische Wochenschrift 69:2378-2383

Westhoff AO (2007) Die Verbreitung der englischen Limited mit Verwaltungssitz in Deutschland. GmbH-Rundschau 98:474-480 